\title{
THE DEVIL WITHIN
}





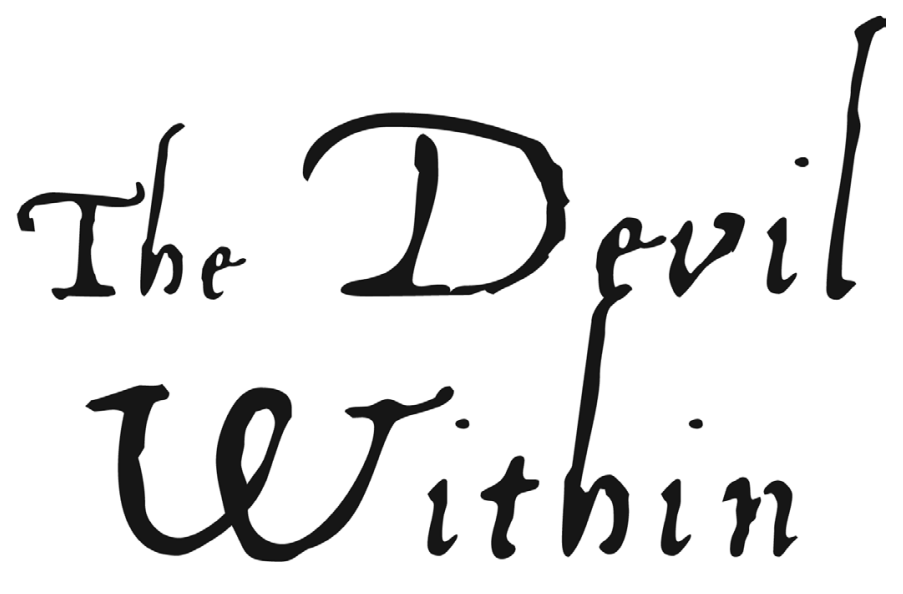

Possession E Exorcism
in the Christian West

BRIAN P. LEVACK 
Copyright (C) 2013 Brian P. Levack

All rights reserved. This book may be reproduced in whole or in part, in any form (beyond that copying permitted by Sections 107 and 108 of the U.S. Copyright Law and except by reviewers for the public press) without written permission from the publishers.

For information about this and other Yale University Press publications, please contact: U.S. Office: sales.press@yale.edu www.yalebooks.com

Europe Office: sales@yaleup.co.ukwww.yalebooks.co.uk

Set in Adobe Caslon Pro by IDSUK (DataConnection) Ltd

Printed in by TJ International Ltd, Padstow, Cornwall

Library of Congress Cataloging-in-Publication Data

Levack, Brian P.

The Devil within : possession and exorcism in the Christian West / Brian Levack. pages $\mathrm{cm}$

ISBN 978-0-300-11472-0 (cl : alk. paper)

1. Exorcism-Europe-History. 2. Demoniac possession-Europe-History. I. Title. BV873.E8L48 2013 $133.4 ' 26094-\mathrm{dc} 23$

A catalogue record for this book is available from the British Library

10988765543321 